811.163.41'367.634

https://doi.org/10.18485/sj.2017.22.1.13

ВЕСЕЛИНА В. ЂУРКИН

Универзитет у Новом Саду

Педагошки факултет у Сомбору

Катедра за језик и књижевност
Оригинални научни рад

Примљен: 01. 06. 2016.

Прихваћен: 15. 12. 2016.

\title{
СИСТЕМ СЛОЖЕНИХ КОНЦЕСИВНИХ ВЕЗНИКА У СРПСКОМ ЈЕЗИКУ**
}

У раду смо на функционалностилски разноликом корпусу текстова, примјеном структурно-семантичке методе и методе функционалностилске дистрибуције, анализирали сложене везнике концесивне семантике у српском језику. На основу творбеног модела према којем су формирани, сложени концесивни везници се могу подијелити у двије велике скупине: 1) сложене концесивне везнике творене преко прилошких израза приједлошко-замјеничког типа (упркос томе што, без обзира (на то) што итд.) и 2) сложене везнике творене у процесу удружења партикуле и везника или лексеме замјеничког поријекла и/или типа (макар да, макар што, и поред тога што, који год, како годитд.). У оквиру обје скупине реализују се оба семантичка подтипа - општеконцесивни и парцијалноконцесивни. Даља класификација вршена је с обзиром на (не)реализацију катафорске демонстративне замјенице у експлицитној структури везника, с обзиром на позицију у којој је реализована обликотворна партикула и на основу везничког елемента који учествује у стварању сложеног везника (да ли је прост или сложен, семантички недиференциран или семантички одређен).

Кључне ријечи: сложени везници концесивне семантике, творбени модели, функционалностилска дистрибуција, српски језик

*veselinaso@gmail.com

${ }^{* * *}$ Рад је урађен у оквиру пројекта 178014 Динамика структура савременог српског језика, који финансира Министарство за науку, технологију и развој Републике Србије. 


\section{УВОД}

0. Однос концесивности сматра се једним од најкомпликованијих односа не само у синтакси већ и у језику уопште. Ради предочавања сложености концесивне семантичке категорије Пипер (2005: 826) даје подробнији увид у ситуативни оквир концесивног значења, констатујући да је концесивност „очигледно категорија комплексног садржаја са елементима и каузативности, и модалности (...), и адверзативности", те да управо из тог разлога и спада у ред слабије развијених семантичких категорија у језику, са „сразмерно малим избором облика", који се своде на зависносложену концесивну реченицу ${ }^{1}$ или на просту реченицу (са глаголским прилогом као полупредикативним елементом или с предлошко-падежном конструкцијом у адвербијалној функцији). Уз то, субординација је најтипичнији и далеко најчешћи начин исказивања концесивности.

У литератури је већ истакнута чињеница да је концесивни семантички однос међу клаузама, паралелан, с једне стране, с узрочно-посљедичним, a c друге с погодбеним односом и да се веза концесивности и каузалности потврђује анализом семантике сложених реченица с концесивном зависном клаузом. Концесивни однос посматра се као подврста каузалног односа - концесивна клауза узима се као каузална, а надређена као консекутивна ${ }^{2}$. Пишући о концесивности као негацији каузалне везе, Ковачевић (2002: 142) наглашава да се „Суштина суодноса концесивности и каузалности исцрпљује (се) одговором на питање шта условљава реализацију посљедице истовремено спречавајући дјеловање у концесивној клаузи експлицираног узрока?” Он закључује да су „на језичком плану у суоднос доведени посљедица без свог узрока и узрок без своје посљедице”, те да су „садржаји сложене реченице с концесивном клаузом само привидно логички неусаглашени”, што уједно показује „да је каузални ланац у експлицитно наведеном језичком материјалу нужно редукован из комуникативних и/или стилских разлога" (Исто, 142-143).

Као „усаглашивачи” логички конфликтних садржаја зависне и надређене клаузе у језику функционишу концесивни везници. С обзиром на то да сложене реченице субординацијског типа представљају „најмлађе језичке структуре у развоју синтаксичких конструкција”, а да су као специфична средства изражавања концесивности на нивоу хипотаксе у језику најпослије формирани сложени везници (поред секундарних приједлога и приједлошких израза)

\footnotetext{
${ }^{1}$ O могућности изражавања концесивног значења и координацијом в. Прањковић 2001: 50.

2 Према томе, концесивне би се клаузе разликовале од узрочних по томе што „uzročne pretpostavljaju dovoljan uzrok, a dopusne nedovoljan (ili uzročno-posljedični odnos razbijen suprotnošću). Na vrlo se sličan način dopusne rečenice razlikuju i od pogodbenih (uvjetnih), naime što pogodbene podrazumijevaju dovoljan uvjet, kao što i uzročne pretpostavljaju dovoljan uzrok" (Прањковић 2001: 50).
} 
(Исто, 152), можемо рећи да сложене реченице са зависном клаузом уведеном сложеним концесивним везником језички одражавају семантичку категорију концесивности у најчистијем виду.

Систем сложених концесивних везника један је од многобројнијих, ако не и најмногобројнији, у српском језику, што несумњиво има везе са чињеницом да ни „саме концесивне клаузе нису ни синтаксички ни семантички једнородне”, него се, како је то уочила К. Милошевић (1986: 33-45), „остварују у два различита модела": а) опитеконцесивном у којем, по ријечима ауторке, предмет допуштања није обиљежен неким граматичким средством и б) nаричјалноконщесивном, за који је карактеристично да се концесивни чинилац укључује у семантичку структуру различитих стандардних семантичких модела субординираних клауза и на тај начин је осложњава. Након прегледане сербокроатистичке граматичке литературе - старије и новије - можемо констатовати да не постоје два аутора код којих је списак концесивних субјунктора подударан ${ }^{3}$. Међу њима најобимнији и облички најразноврснији репертоар допусних субјунктора налазимо у граматици П. Мразовић (2009). Инвентар сложених концесивних везника у нашим старијим граматикама углавном се своди на концесивне везнике који у своме саставу садрже партикулу ( $и$ ако, $u$ да, и кад, макар да, ко год, колико год, било који и сл.), док се сложени концесивни везници настали преко катафорски употријебљених прилошких израза (без обзира (на то) што, упркос томе што, и поред тога што, насупрот томе што) готово и не помињу (Ђуркин 2011: 234).

Проведена анализа показује да се на основу творбеног модела према којем су формирани, сложени концесивни везници могу подијелити у двије велике скупине: 1) сложене концесивне везнике творене преко прилошких израза приједлошко-замјеничког типа (упркос томе што, без обзира (на то) што итд.) и 2) сложене везнике творене у процесу удружења партикуле и везника или лексеме замјеничког поријекла и/или типа (макар да, макар што, и поред тога што, који год, како год итд.). У оквиру обје скупине реализују се оба семантичка подтипа - општеконцесивни и парцијалноконцесивни. Даља класификација вршена је с обзиром на (не)реализацију катафорске демонстративне замјенице у експлицитној структури везника, с обзиром на позицију у којој је реализована обликотворна партикула и на основу везничког елемента који учествује у стварању сложеног везника (да ли је прост или сложен, семантички недиференциран или семантички одређен).

${ }^{3}$ Исцрпан преглед и старије и новије граматичке и научне сербокроатистичке литературе даје Ковачевић 2008. 


\section{1. СЛОЖЕНИ ВЕЗНИЦИ КОНЦЕСИВНОГ ЗНАЧЕЬА ТВОРЕНИ ПРЕКО ЗАМЈЕНИЧКИХ ПРИЛОШКИХ ИЗРАЗА}

С обзиром на чињеницу да категорија концесивности спада у ред оних семантичких категорија које није могуће изразити замјеничким прилозима, већ само замјеничким прилошким изразима којима се попуњава празно мјесто у семантичкој парадигми замјеничких прилога, логично је очекивати да је барем један дио сложених концесивних везника у српском језику настао управо преко замјеничких прилошких израза концесивне семантике. Према томе да ли се као интегрална структурна компонента сложеног концесивног везника, поред концесивног замјеничког прилошког израза, појављује семантички неспецификован везник што или замјеничка лексема (као везнички елемент), сложене концесивне везнике можемо разврстати у двије групе: 1) општеконцесивне и 2) парцијалноконцесивне.

\section{1. Општеконцесивни}

У процесу обједињења катафорски употријебљеног концесивног замјеничког прилошког израза и експликативног везника што, као номинатори концесивне семантичке релације међу клаузама, у српском језику настали су сложени концесивни везници: упркос томе што, без обзира (на то) што, уз (а) све то што, насупрот томе што, поред тога што, покрај тога што, поврх тога што, мимо тога што. Према томе да ли је демонстративна замјеница то, исказана у дативној, акузативној или генитивној падежној форми, обавезан или испустив елемент сложеног концесивног везника, сложене концесивне везнике овога типа могуће је разврстати у два (под)модела: 1) сложене везнике општеконцесивног значења са катафорском демонстративном замјеницом као обавезним елементом и 2) сложене везнике општеконцесивног значења са катафорском демонстративном замјеницом као факултативним елементом.

1.1.1. За потврду сложених везника реализованих према првом структурном моделу наводимо примјере регистроване у различитим функционалним стиловима српског језика, при чему ћемо њихово значење утврђивати примјеном теста супституције, тј. замјеном датих везника општеконцесивним простим везником иако:

Биле су свеже упркос томе што $[\rightarrow$ иако $]$ је кухиња била топла, а она радила све домаће послове сама (Г. Олујић, Гласам за љубав, 30, АСК);Пригодна поезија, .., упркос томе што $[\rightarrow \boldsymbol{u a \kappa o ] ~ j е ~ ч е с т о ~ п а т и л а ~ о д ~ н е и з л е ч и в о г ~ о д с у с т в а ~ и с к р е н о с т и , ~ п р а т и ~ н е к е ~}$ моменте Пасквалићевог живота или живота његових пријатеља (М. Пантић, Књижевност на тлу Црне Горе и Боке Которске од XVI до XVIII, Р); Али, упркос томе што СОФА гарантује одређене механизме домаћину да се заштити, истина је да спровођење правде може донети и те какве проблеме (НИН, бр. 2848, 28. 7. 2005); Preživeo sam nasuprot tome što $[\rightarrow$ иако $]$ sam znao da najvažnije još nedostaje (www.zetna.org/zek/folyoiratok/18/hyper1. 
html-Мађарска, 23. 2. 2012); ... Istanbul (...) nasuprot tome što $[\rightarrow$ иако $]$ je toliko otvoren za spoljne uticaje, vodi zatvoren mahalski i društveni život ... (www.delfi.rs/ka1fi5di1444/ delfi_knjige_autor_orhan_pamuk.html, 23.2.2012); ... uza sve to što[ $\rightarrow$ iako]je bio tvrdica, on nije žalio da, svakom prilikom, počasti i pogosti što bolje može stariju gospodu od sebe ... (В. Милићевић, Беспуће, КССЈ); Поред тога што $[\rightarrow$ иако $]$ врло добро познаваше Златета, Јаковчетов се никако не надаше имати овакав одговор (Г. Божовић, Злате из Слатине, АСП); Naime, problem je u tome što već neko vreme gubim na težini i osećam stalnu glad povrh toga što[ $\rightarrow$ iako]se hranim redovno i u više nego dovoljnim količinama (www. doktor.rs > Zdravlje forum > Medicina > Pitanja i odgovori, 6.3.2012); Mimo toga što[ $\rightarrow$ iako] parlamentarne stranke na sva zvona zvone o novom ustavu, a ni pedalj se ne miču s mrtve tačke, u vladajućem DSS-u tvrde da Srbija u septembru može imati najviši pravni akt (www. glas-javnosti.rs/node/24925/print); Покрај тога што[ $\rightarrow$ иако] је највиши Суд правде у свету пресудио онако како је утврдио на основу докумената за и против, и даље одзвањају повици: распните, распните српски народ! (forum.vidovdan.org > Традиција и вера > Православље - теорија, 6.3.2012).

Доказ да су све компоненте датих сложених везника обликотворног карактера јесте немогућност њиховог елидирања или, пак, постављања у дистактни положај, а да при том не дође до оштећења на синтаксичко-семантичком плану. Замјенички прилошки израз у наведеним реченицама није структурни елемент надређене клаузе, већ интегрални дио сложеног субординацијског везника, на што упућује не само чињеница да је обавезан контактни положај прилошког израза и везника што него и чињеница да те двије компоненте чине интонационо, па према томе, структурно и семантички, недјељиву цјелину.

1.1.1.1. Од свих везника који су формирани на описани начин, једино је везник упркос томе што, захваљујући моносемичности приједлога упркос, једнозначно концесиван, тј. контекстуално неусловљен. Својом семантиком он једнозначно предодређује семантички тип релације међу клаузама које доводи у суоднос. Премда приједлог упркос у српском језику може бити употријебљен и уз генитивну падежну форму (Антонић 2005: 172), демонстративна замјеница то у саставу овог сложеног везника искључиво се јавља у дативу, што је у складу са иначе преовлађујућом употребом овога приједлога у српском језику (в. Пипер 2005: 828).

1.1.1.2. Чињеница да је значењу концесивности иманентна семантичка компонента контрастности односно супротности (иначе несвојствена каузалној и/ или погодбеној реченичној структури) (Милошевић 1986: 42), да у допусном односу „,uzrok ili uvjet biva 'razbijen' suprotnošću, pa je zato u njemu posljedica (odnosno ono što stoji nasuprot uvjetu, tj. 'upitana' posljedica) suprotna očekivanoj” (Прањковић 2001: 48), јасно је осликана у семантици интегралних компонената сложеног везника насупрот томе што.

О лексеми насупрот говори се као о приједлогу који у споју са именском ријечју у дативу „у конкретном просторном смислу упућује на лоцираност два објекта у простору који су окренути један према другоме” (Антонић 2005: 192), 
уз напомену да се дати приједлог, односно датив с приједлогом насупрот, у посебним функционалним стиловима појављује „и ван конкретног просторног значења, али концептуално заснован на тој семантичкој категорији, у апстрактном смислу" с опозитним значењем, тј. значењем супротстављања. Такође су у научној литератури забиљежени примјери употребе лексеме $н а$ cynрот као приједлога који учествује у формирању замјеничког прилошког израза насупрот томе, који служи за исказивање значења контрастности, које у језику није могуће изразити замјеничким прилозима, усљед чега се дати прилошки израз јавља као резултат компензације тог недостатка (Ковачевић 2009: 17). Захваљујући управо семантици прилошког израза насупрот томе, тачније приједлогу насупрот у саставу тог израза, у реченицама са сложеним везником насупрот томе што у први план се поставља значење опозитности, контрастности као једне од двију семантичких компонената концесивности, која на логичко-семантичком плану представља резултат синтезе двију компонената — „значења каузалне условљености (иманентни однос) и значења супротности (суоднос језички експлицираних садржаја)“ (Ковачевић 2002: 144). Будући да се прилошким изразом насупрот томе у језику изражава значење контрастности, сложени везник насупрот томе што припада категорији контекстуално условљених сложених везника концесивне семантике. Сви примјери сложеног везника насупрот томе што ексцерпирани су махом из текстова публицистичког функционалног стила.

1.1.1.3. Прилошки израз уз (a) све то у саставу сложеног везника уз(a) све то што сигнализира да се информација изнесена зависном клаузом додаје, прикључује, прибраја претходно реченом, што је у складу са оним што у вези са датим прилошким изразом у функцији конектора каже Д. Кликовац (2008: 180). Поредећи конектор уз (све) то са конектором поред свегатога, ауторка каже да сеовај други „готово аутоматски чита као допусни, што није случај за уз све то", што значи да је коцесивна семантика сложеног везника уз (a) све то што формираног преко прилошког израза уз (a) све то контекстом предодређена.

1.1.1.4. Сложени везници поред тога што, покрај тога што, поврх тога што, мимо тога што, карактеристични прије свега за публицистички и научни функционални стил, такође немају улогу једнозначних номинатора концесивног типа семантичке релације међу клаузама будући да могу бити реализовани и као сложени везници ексцептивне и као сложени везници концесивне семантике, што је посљедица вишезначности прилошких израза преко којих су творени, односно приједлога као структурних елемената тих израза. ${ }^{4}$

${ }^{4}$ О структурном и семантичком статусу ових везничких јединица и њиховој функционалностилској репартицији у српском језику в. Ђуркин 2014. 
1.1.2. Међу сложене везнике настале преко замјеничких прилошких израза са експлетивном катафорски употријебљеном демонстративном замјеницом то спадају сложени везници без обзира (на то) што ибез обзира (на то) да ли. Само катафорски употријебљен прилошки израз у структури зависносложене реченице, када се нађе у контактном положају са семантички недиференцираним везником што, при чему „релативна клауза заправо 'идентификује' значење имплицитно или експлицитно присутне демонстративне замјенице у саставу тог прилошког израза" (Ковачевић 2009: 131), и субординатором $\partial a$ $л и$, може учествовати у творби сложеног субординацијског везника концесивног значења, што потврђују примјери забиљежени углавном у специјалним стиловима српског језика, уз напомену да је знатно фреквентнија варијанта са елидираним замјеничким елементом:

... без обзира ито $[\rightarrow$ иако $]$ у појединим моментима можемо сматрати да је једна опасност већа од друге, оба гледања представљају подједнаку ревизију марксистичког погледа на национално питање... (Југославија 1918-1984, 984); На том дубљем, структурном плану сви наши реалистички приповедачи били су марковићевци, без обзира на то што[ $\rightarrow$ иако] су неки од њих у својим политичким идејама његове присталице, $a$ други огорчени противниции (Ј. Деретић, Кратка историја српске књижевности, П); Ако приговор из става 1. овог члана садржи и одређене доказне предлоге, председник већа ће их размотрити по службеној дужности, без обзира ито $[\rightarrow$ икко $]$ је донео решење из става 1. овог члана (Законик о кривичном поступку, чл. 294, ст. 2, Зак.); Тамо, ако се коме просиочу допадне удата жена, он је проси без обзира на то ито $\rightarrow$ иако] она има жсивог мужа (Б. Нушић, Госпођа министарка, 93, АСК); За посланика у Народној Скупштини може бити изабран само онај, који има бирачко право, без обзира да ли је уведен у бирачки списак (Југославија 1918-1984, 179); Познавање веровања, обичаја и обреда односи се искључиво на знање испитаника о традиционалним обичајима и веровањима који су везани за одрастање деще, без обзира на то да ли се он лично држи тих обичаја или их се не држи, односно да ли верује или не верује у юихову делотворност (Ж. Требјешанин, Представа о детету у српској култури, АСК); A kako god okrenete, TV drama, čak i najbolja, nužno je nusprodukt, samim tim što je namenjena masovnom mediju $i$ što vas televizija, bez obzira da li ima dva ili dvadeset šest programa, stavlja pred svoj izbor, a ne pred vaš sopstveni (Д. Киш, Горки талог искуства, СДДК).

Да компоненте датих сложених везника заиста чине структурно и семантички јединствену, недјељиву цјелину, доказ је то што није могуће изоставити прилошки израз, а да при том реченична структура не буде обесмишљена, неграматична.Зависном се клаузом уведеном сложеним субјунктором без обзира (на то) да ли износе обично двије или више (углавном) међусобно супротстављене могућности, чија реализација (а може бити реализована само једна), супротно очекивању, нема значаја за остварење садржаја главне клаузе. Могућност супституције замјеничког прилошког израза без обзира на то лексемом свеједно јасно показује да је за реализацију садржаја главне клаузе апсолутно небитно која ће од двију или више изнијетих могућности (за које се сматра да би могле бити препреком остварењу садржаја у главној клаузи) у зависној клаузи бити реализована: За посланика у Народној Скупштини може 
бити изабран само онај, који има бирачко право, без обзира $[\rightarrow$ свеједно $]$ да ли је уведен у бирачки списак.

\section{2. Парцијалноконцесивни}

Концесивни прилошки израз без обзира на то може учествовати и у формирању сложених везника парцијалноконцесивног значења када са неком замјеничком лексемом (односно-упитне замјенице и замјенички прилози), замјеничким узрочно-упитним или финално-упитним прилошким изразом (због чега, ради чега) чини структурно и семантички недјељиву цјелину, која у сложену реченичну структуру уводи зависну клаузу парцијалноконцесивног типа: без обзира (на то) ко, без обзира на то који/какав/колики/чији, без обзира (на то) гдје/ одакле/ откуда, без обзира (на то) када, без обзира (на то) како, без обзира (на то) колико, без обзира на то зашто/због чега/ ради чега. Дати прилошки израз, као интегрална семантичка компонента сложеног везника, семантички је експонент концесивне релације, тј. концесивни чинилац који се укључује у разне стандардне семантичке моделе субординираних клауза обогаћујући на тај начин базични семантички однос међу клаузама.

Зависно од тога с којом се замјеничком лексемом (упитно-односном замјеницом или замјеничким прилогом) или замјеничким прилошким изразом комбинује, употребом прилошког концесивног израза без обзира на то, уз могућност факултативне редукције катафорски употријебљене демонстративне замјенице то, „укида се ограничење у погледу идентитета субјекта”, „идентитета објекта”, „у погледу квалитета (особине) појава или предмета”, „у погледу локалне, темпоралне, квантитативне детерминације”, „у погледу начина, карактера, исхода, узрока или сврхе радње”, „у погледу комплемента семикопулативног глагола" (Милошевић 1986: 39-41) и посесивне детерминације (Ковачевић 2008: 75). Сложени везници овога типа јављају се специјалним функционалним стиловима српског језика:

Поверилац има право приступа непокретности, укључујући и улазак у непокретност без обзира ко се у ьој налази ... (Закон о хипотеци, чл. 17, Зак.); .. он уме и сме да мисли својом главом, без обзира на то шта ће други рећи (Ј. Деретић, Историја нове српске књижевности, АСК); Сматрао сам и сматрам да за јавну бригу о језику, (из)говору и писму нису надлежни само лингвисти, него и други језикословци, без обзира на то којим се послом баве (Б. Брборић, С језика на језик); .. али ми, без обзира какав је прави циљ покривања, хоћемо да подвучемо само један факат... (В. Чајкановић, Мит и религија у Cpба, ACK); Svaki je činovnik odgovoran za svoja službena dela, bez obzira na topo čijim je naredbama radio (Устав 1903, чл. 184); Кривично законодавство Србије важи и за сваког ко учини кривично дело у домаћем иивилном ваздухоплову док је у лету или у домаћем војном ваздухоплову, без обзира где се ваздухоплов налазио у време извриења кривичног дела (Кривични законик, чл. 6, Зак.);... те да службеници, наставниции и јавни радниции, без обзира откуда потјецали, службено употребљавају књижевни језик средине у којој дјелују (Б. Брборић, ОЈР); ... утврђивање заједничких говорних карактеристика по којима се наводно, упркос двама јасно разлученим дијалекатским типовима, Црногорци лако 
препознају без обзира на то одакле долазем ... (Б. Брборић, ОЈР); Прекршај је извршен у време када је учинилач радио или био дужан да ради, без обзира када је последица наступила (Закон о платама државних службеника и намештеника, чл. 11, Зак.); ... полиција може странца лишити слободе(...), на основу молбе надлежног иностраног органа, без обзира како је упућена (Законик о кривичном поступку, чл. 520, Зак.); Писаи мора да живи у својим временима, без обзира на то колико их има (Ј. Михајловић, Прича о души и телу, Р); Bez obzira na to zašto se Balkan zove Balkan, ako na turskom to stvarno znači med $i$ krv, onda je to jako zanimljivo i može se iskoristiti na način na koji je A. Žoli to uradila (www.rts.rs > Насловна > Вести > Култура); Rusija, kao i mnoge druge zemlje, u principu se protivi smrtnoj kazni, bez obzira zbog čega je izrečena... (Политика, 30. 12. 2006, КССЈ); Za članstvo u ortaštvu bitno je da je riječ o pravnoj osobi bez obzira na to radi čega je osnovana... (www.scribd.com/.../KORPORACIJSKO-PRA... 2. 3. 2012).

Спој допусног и другог значења у датим реченичним моделима оличен је у структури сложеног субјунктора чији су нужни елементи прилошки израз приједлошко-замјеничког типа без обзира (на то), као носилац концесивне семантике, и замјеничка лексема или замјенички (узрочно-упитни или финално-упитни) прилошки израз као експонент семантике која се са концесивном комбинује. Да је прилошки израз постао интегрални дио сложеног везника, јасно је по томе што реченични модел с датим значењем зависне клаузе уопште није могуће реализовати уколико га изоставимо.

\section{2. СЛОЖЕНИ ВЕЗНИЦИ КОНЦЕСИВНОГ ЗНАЧЕЊА СА ПАРТИКУЛОМ КАО ОБАВЕЗНОМ ИНТЕГРАЛНОМ КОМПОНЕНТОМ}

Поред везника, „као семантичких експонената концесивних релација у сложеној реченици", веома важну улогу у обликовању концесивне везе имају и разне концесивне партикуле (Милошевић 1986: 43). Оне су заправо носиоци или појачивачи концесивног значења и ,,vrlo često dolaze uz druge (nedopusne, ali uglavnom 'hipotetične') veznike te ih 'koncesuiraju' unoseći zapravo u dijelove rečenica u kojima dolaze svojevrsnu negaciju, pa time signaliziraju nedovoljnost uzroka ili uvjeta sadržanog u zavisnoj klauzi i sugeriraju posljedicu suprotnu očekivanoj sadržanoj u glavnoj klauzi. Uostalom, i danas najobičniji dopusni veznici zapravo su sastavljeni od veznika i takvih čestica. Tako iako nije ništa drugo nego $i$ + ako, mada nije ništa drugo nego ma(kar) + da, premda je prem(a) + da" (Прањковић 2001: 50-51). Будући да у реченичну структуру уносе допунску негацију, интензификатори се, с једне стране, појављују као средства за усаглашавање логички конфликтних (неусаглашених, неуравнотежених) садржаја надређене и зависне клаузе, или, с друге стране, као средства помоћу којих се могу нарушити логички уравнотежени садржаји датих клауза (Силић 1984: 81-83).

О значају партикула у конституисању и интерпретацији концесивне семантичке релације посредно свједоче и спискови концесивних везника који се могу наћи у сербокроатистичкој граматичкој литератури, међу којима 
су, свакако, најбројнији они који у свом саставу садрже партикулу у улози интензификатора. Исцрпан преглед досадашњих „србистичких и/или сербокроатистичких запажања о концесивним везницима и (не)обавезном учешћу партикула у њиховој творби” даје М. Ковачевић и закључује да „не постоје два аутора код којих је списак концесивних субјунктора подударан” нити да постоји сагласност у погледу статуса елемената сложених концесивних субјунктора код свих аутора (Ковачевић 2008: 68). ${ }^{5}$ Пишући о улози партикула у конституисању и интерпретацији концесивне релације реченичног типа, Ковачевић све у анализу укључене партикуле комбинаторне с (не)концесивним везницима, с обзиром на то да ли су значајне за синтаксу, семантику или прагматику концесивне релације, класификује у три категорије: а) обликотворне, б) верификативне и в) плеонастичке (Исто, 81). Као критеријуме разграничења наводи позицију партикуле у односу на субјунктор и тест (не)осјетљивости на правило о конгруенцији негација и афирмација у реченици и доказује да спој партикуле и субјунктора у српском језику функционише као сложени везник само уколико је партикула његова интегрална, неизостављива компонента. Елидирањем партикуле реченица уведена датим сложеним везником би била или граматички неприхватљива или би промијенила значење.С обзиром на позицију у којој се партикула реализује, могуће је издвојити двије групе везника: 1) сложене везнике концесивне семантике са антепонираном партикулом и 2) сложене везнике са постпонованом партикулом (год).

\section{1. Сложени везници са антепонованом партикулом}

За разлику од сложених везника са постпонованом партикулом год, који у српском језику могу бити остварени једино у парцијалноконцесивном значењу, сложени везници са антепонованом партикулом реализују се у општеконцесивном и парцијалноконцесивном значењу.

\subsection{1. Општеконцесивни}

Како проведена анализа показује, у оквиру датога подмодела према којем су творени сложени везници општеконцесивне семантике, на основу субјунктивног елемента у структури сложеног везника могу се издвојити двије групе сложених везника: 1) сложени концесивни везници са зависним везничким елементом и 2) сложени концесивни везници са лексемом замјеничког типа и/или поријекла.

2.1.1.1. С обзиром на то да ли је носилац граматичког значења субординативности изражен простим или сложеним везником, сложени везници

${ }^{5}$ Ковачевић уочава да поменута неподударност потиче првенствено од проблема везаног за диференцијацију везника и партикула у случају хомоформних лексема (Исто, 69). 
формирани према датоме моделу класификују се на: 1) сложене концесивне везнике настале у процесу удружења партикуле и сложеног зависног везника и 2) сложене концесивне везнике творене у процесу удружења партикуле и простог зависног везника.

2.1.1.1.1. Реализована испред сложених везника поред/покрај/поврх тога што,мимо тога што када је њима обиљежено ексцептивно значење комитативног типа уз обавезно присутну семантичку компоненту контрастности, интензификаторска партикула $u$ формира са датим везницима сложени везник општеконцесивног значења $и$ поред/покрај/поврх тога што, и мимо тога што. Статус обликотворне, интегралне компоненте дата партикула има само уколико обезбјеђује једнозначно концесивну интерпретацију реченице, док могућност њеног елидирања или премјештања у односу на субјунктор без посљедица по концесивну семантичку интерпретацију реченице указује на њен верификативни карактер. ${ }^{6}$

2.1.1.1.2. Сложени концесивни везници настали као резултат обједињења интензификаторске партикуле и простог везника, могу се даље разврстати према семантичком типу простога везника у њиховом саставу.

2.1.1.1.2.1. Сложени концесивни везници настали удруживањем партикуле и везника условне семантике представљају један од доказа да се језик, прије формирања везничких средстава специјализованих искључиво за исказивање концесивног реченичног значења, користио примарно условним везницима ако, кад, да, уколико, односно конективним индикаторима погодбене реченице ${ }^{7}$. Због поливалентности датих везника допусно значење, осим контекстом, бива сигнализовано и додатним формалним маркерима (или искључиво њима), какви су нпр. партикула $u$, која у реченици функционише као „индикатор релацијске коегзистенције неадекватног, односно недостатног услова и последице" и може бити у контактној или дистактној позицији са условним везником ако, кад, да, уколико, и одговарајући кореференти употријебљени уз негирану управну предикацију.

Нужан, али не и довољан услов настанка сложених концесивних везника овога типа јесте контактна позиција интензификаторске партикуле $u$ и везника условне семантике. Да би спој партикуле $u$ и везника погодбеног значења у српском језику имао статус сложеног концесивног везника, неопходно је да партикула $u$ буде антепонирана. Тек употријебљена испред датих везника, интензификаторска партикула $u$ добија обликотворни карактер, „концесуира” условни везник уз који се нашла, укидајући му погодбено а задајући концесив-

\footnotetext{
${ }^{6}$ Подробније о улози и значају партикуле $u$ у образовању концесивне семантике датих сложених везника в. Ђуркин 2014.

${ }^{7}$ Павловић (2009: 333) наводи да се у старосрпској пословноправној писмености допусна реченица уводи везницима који фунгирају и као конективни индикатори погодбене реченице.
} 
но значење, тј. постаје интегрална семантичка компонента сложеног концесивног везника ${ }^{8}$. Обликотворни статус партикуле одражава се у немогућности њеног испуштања из сложеног везника без посљедица на семантичком плану реченице, док се семантичка вриједност датога везника потврђује у могућности његове супституције простим везником општеконцесивног значења иако. Веома је важан и критеријум неосјетљивости на негацију приликом утврђивања обликотворне улоге интензификаторске партикуле $u$. Будући да је неодвојиви дио сложеног везника, дата партикула не конгруира са негацијом предиката надређене клаузе, тј. не бива замијењена партикулом ни као својим негираним еквивалентом. Када не би имала обликотворни карактер, партикула $u$ би морала бити супституисана партикулом $н и$, што је у складу са правилом о конгруенцији ни са негираним предикатом (Ковачевић 2008: 72; 2002: 33-57). Претходно речено потврдићемо сљедећим примјерима:

И из овога се примјера види да се људи некад куну и ако $[\rightarrow$ иако] нијесу сигурни (што је често и немогуће) да су у праву, већ просто то чине на вјеру и повјерење другијех људи (В. С. Караџић, Црна Гора и Црногорци, Р); ... ali čak $\underline{\boldsymbol{i} \text { ako }}[\rightarrow \boldsymbol{i a k o}]$ ga je bilo, Nihil ga je u međuvremenu potpuno zaboravio (В. Арсенијевић, Предатор, КССЈ); И ако [ $\rightarrow$ иако] је од Бога - доста је (Ковачевић 2008: 72, В. Николић); Резултати су показали да брак, чак и ако[ $\rightarrow$ иако] је далеко од идеалног, пружа велики психолошки подстицај депресивним људима (Ковачевић 2008: 80, Вечерње новости); Чак и кад не бибило времена за производюу нове вакиине, већ постојећа би била такође делотворна, можда са неким малим процентом промамаја (НИН, 2861, 27. 10. 2005); Ниједан сунчани зрак не би могао продрети овамо до овог слоја атмосфере Земљине све и кад не би била обавијена својим непродорним облацима, јер би га сува водена пара прогутала (М. Миланковић, Кроз васиону и векове, АСК); И да их је звао, не би му дошли (Ковачевић 2008: 73, Правда); Дакле, и да су причали, не би се разумели (Ковачевић 2008: 73, Прес); И да је било обрнуто, не би било неправедно (Ковачевић 2008: 73, Вечерње новости); Ако се обистине најаве ДС да ће избори бити расписани чак и уколико изостане договор са ДСС, Србија би могла остати без председника, али и без Владе (Ковачевић 2008: 80, Курир); Čak i ukoliko živite u severnijim krajevima, možete prikupljati insekte tokom cele godine (www.zivotinje.rs/enciklopedijaStrana.php?id=2798\&alias...za...); Lice koje je obuhvaćeno abolicijom ne može se krivično goniti čak i ukoliko postoji osnov za krivično gonjenje (sh. wikipedia.org/wiki/Abolicija).

Да је партикула $u$ позиционирана испред везниказаиста обликотворног карактера ${ }^{9}$, доказује немогућност њеног елидирања из састава сложеног везника, а да се при том не промијени семантички тип зависне клаузе:

${ }^{8}$ Позиционирана иза везника, партикула $u$, будући одвојива од субјунктора, нема обликотворну већ верификативну семантичку улогу - њоме се, дакле, само наглашава концесивна семантичка интерпретација клаузе.

9 Забиљежили смо и један примјер сложеног везника у којем статус обликотворне партикуле има лексема макар - макар ако: Макар ако $\rightarrow \rightarrow$ иако/ без обзира на то што] се на мене срдии, опет ћу да те пољубим (Ј. С. Поповић, Женидба и удадба, 47, АСК). Семантичка вриједност датога споја потврђује се примјеном теста супституције. Умјесто партикуле макар може бити употријебљена обликотворна партикула $u:$ Maкар $[\rightarrow \boldsymbol{U}]$ ако се на мене срдиш, опет ћy да те пољубим. 
Ииз овога се примјера види да се људи некад куну и ако $[\rightarrow \boldsymbol{a \kappa o}]$ нијесу сигурни (ито је често и немогуће) да су у праву, већ просто то чине на вјеру и повјерење другијех људи; Ниједан сунчани зрак не би могао продрети овамо до овог слоја атмосфере Земьине све и кад [ $\rightarrow \boldsymbol{к а д ] ~ н е ~ б и ~ б и л а ~ о б а в и ј е н а ~ с в о ј и м ~ н е п р о д о р н и м ~ о б л а ц и м а , ~ ј е р ~ б и ~ г а ~ с у в а ~ в о д е н а ~}$

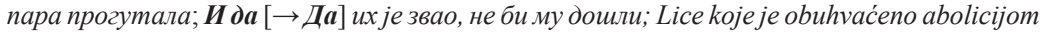
ne može se krivično goniti čak $\boldsymbol{i}$ ukoliko $[\rightarrow \boldsymbol{u}$ koliko] postoji osnov za krivično gonjenje.

За разлику од везника са интензификаторском партикулом $u$, који су једнозначни номинатори концесивне семантичке релације међу клаузама, сложени везник $а$ дапоред концесивног може имати и нека друга значења, као што су нпр. пропратнооколносно или атрибутско хабитуално значење, што се види на основу супституције споја $a$ да везничком скупином $а$ да при том ${ }^{10}$ :

Čovek može verovati u Boga, a da $[\rightarrow \boldsymbol{a}$ da pri tom $]$ ne pripada nijednoj veroispovesti (Даница 1995, КССЈ); Кад си за Божић долазио кући, како си смео да прођеш кроз Паланку а да[ $\rightarrow$ a да при том] не свратии код мене (Д. Ћосић, Корени, АСК); Нико у Партизан неће доћи ове зиме, $\boldsymbol{a}$ да $[\rightarrow \boldsymbol{\kappa} \boldsymbol{0}]$ претходно не добије сагласност Јиргена Ребера (Ковачевић 2008: 74).

Због тога што се не остварује увијек са концесивним значењем, већ може имати и друга значења, везник $a \partial a$ не спада у класу чисто концесивних, контекстуално неусловљених везника. Да дати везник има концесивно значење, види се на основу могућности његове замјене неким од везника општеконцесивног значења иако, мада, премда, што потврђују сљедећи примјери:

\footnotetext{
Код нас све траје месеиима и зато афере нестају а да[ $\rightarrow$ иако] се ништа није рашчистило (Ковачевић 2008: 74, Курир); Швајиарска је први тим у историји Мондијала који је елиминисан из даљег такмичень, а да $[\rightarrow$ иако] током меча није примио ниједан гол (Ковачевић 2008: 74, Блиц); Већина света прежсиви читав живот а да[ $\rightarrow$ иако] то никад не доживи (Ковачевић 2008: 74, Вечерње новости); Мене је Веља Илић сменио а $\partial \boldsymbol{a}[\rightarrow$ иако] ме није ни видео (Ковачевић 2008: 80, Вечерње новости); По ко зна који пут опет сам чуо причу о томе колико је недаћа претрпљено у кући због деие, $\boldsymbol{a} \partial \boldsymbol{a}[\rightarrow$ иако] он ни најмағе није био крив (Ковачевић 2008: 80, П. Пајић).
}

Како се из наведених примјера види, да би сложени везник $а$ да имао концесивно значење, поред тога што је нужно да предикат у надређеној клаузи буде у потврдној, а у зависној у негираној форми (што је нужан, али не и довољан услов), обавезно је и присуство значењске компоненте контрастности. Као и сложени везници $u$ ако, $u$ кад, $u$ д $a$ и везник $a \partial a$, реализован у концесивном значењу, најчешће се појављује у текстовима публицистичког и књижевноумјетничког функционалног стила.

2.1.1.1.2.2. Мањи број сложених везника општеконцесивног значења настао је у процесу обједињења партикуле и семантички неспецификованих

${ }^{10}$ На комплексност природе зависносложених реченица с везником $а$ да указао је Љ. Поповић (1972) у своме раду „О начинским реченицама с везником (a) да”, уочивши, прије свега, разлике међу имплицитним и експлицитним класификацијама које се у литератури могу наћи. 
везника што или $\partial a$. Такви су у српском језику сложени везници свеједно што, макар што, макар да, у којима се обликотворни статус партикуле огледа у немогућности њеног елидирања из састава сложеног везника, а општеконцесивна семантика у могућности њихове супституције општеконцесивним простим (иако, мада, премда) или сложеним везницима који у своме саставу имају замјенички прилошки израз (упркос томе што, без обзира (на то) што).

Веома је мали број примјера сложеног везника формираног у процесу срастања партикуле свеједно и семантички недиференцираног везника што забиљежен у нашем корпусу, и сви су углавном ексцерпирани из књижевноумјетничког функционалног стила:

Evo smo pokrenuli jednu velsovsku fantastičnu time machine, vremeplov, svejedno $[\rightarrow$ bez obzira na to]što se ovoga puta kreće unazad, ka vremenima prošlim, kroz antropološke slojeve prošlosti, ... (Д. Киш, Час анатомије, СДДК); Овде је слобода право да хајдукујеш, да хараш, да заузимаш општинске утрине, а демократија и самоуправа да не плаћаш порез, свеједно $[\rightarrow$ без обзира на то] (Д. Ћосић, Корени, АСК);... pravicu se da sam zamišljen i ne primjećujem da nešto čekaju, svejedno $[\rightarrow$ bez obzira na to $]$ što će znati da to nije istina, svejedno $[\rightarrow$ bez obzira na to $]$ što će i oni misliti da izbjegavam njihov pogled (М. Селимовић, Дервиш и смрт); Kladim se da bi samomoji iz kuće kupili najmanje tri primerka te knjige, svejedno[ $\rightarrow$ bez obzira na to $]$ što kažu da su me već odavno pročitali! (М. Капор, Белешке једне Ане).

С обзиром на обимност анализираног корпуса, заступљеност сложених везника творених у процесу повезничења партикуле макар и семантички недиференцираних везника што и да-макар што/да, готово да је незнатна. Углавном су то примјери из текстова књижевноумјетничког и публицистичког функционалног стила:

Узмемо обичаја ради дрвие да прочачкамо зубе, макар ито смо за вечеру само кромпира имали (Грицкат 2004: 202, Јавор, 1875); Ама нису то ловци, макар што носе пушке на плећима (Грицкат 2004: 202, Ст. Новаковић); А макар што има толико пуно разлога у човековој природи ... има ... људи који се никада не опријатеље (Грицкат 2001: 202, Ј. Дучић); Макар што сам болестан и ситан телом, надам се да ме неће Бог милостиви себи позвати пре него урадим што сам намислио ...(politikin-zabavnik. rs/pz/category/broj/3089, 20. 2. 2012); Није окретао главе на другу страну макар што су препелице пућпурикале, жито мирисало и запослени косачи подврискивали (Стевановић 1979: 913, С. Ћоровић); Али макар да у њој ... данас станује читава стотина грађана, сумњам да је у овој згради живот интензивнији и занимљивији (Стевановић 1979: 913, Летопис Матице српске); Гладан пас лаје, макар да су му све овце на окупу (Стевановић 1979: 912); Макар да ну-наставак са собом носи значење свршене радње, има ипак основа ... које задржавају продужено значење (Грицкат 2004: 203, Ст. Новаковић); Макар да беше ђенерал, радовао се (Грицкат 2004: 203, М. Зечевић); Макар да су се Турии храбро одупирали, опет зато наваљиваше Срби (Грицкат 2004: 203, М. Шапчанин); Нушић познаје начине да хипнотише смехом публику, као и Ковачевић, макар да му дела баи и нису комедије, бар не нушићевски чисте (Б. Јакшић-Провчи, Драмски рукописи А. Поповића и Д. Ковачевића, 101, Д); ... јербо и коњи имаду душу, макар да су, што кажу, једна марва (С. Сремац, Поп Ћира и поп Спира, 154, АСК). 
Да спој макар што/да заиста функционише као сложени везник концесивне семантике доказује, с једне стране, немогућност редуковања партикуле из његове структуре (а да реченица при том остане граматична, тј. смислена), а с друге стране, могућност супституције простим или сложеним везником општеконцесивног значењаиако/ без обзира на то ито.

Чињеница да лексема макар у српском језику функционише и као везник којим се у структуру сложене реченице уводе допусне клаузе, како оне чија је радња реализована тако и оне којима се износи потенцијални концесивни услов (Барић и др. 2005: 513), могла би утицати на формирање претпоставке да је главни разлог формирању сложених везника макар што, макар да управо резултат потребе за експлицитним диференцирањем тих двају типова. Томе би у прилог ишли и подаци које у вези с лексемом макар као допусним везником налазимо у рјечнику ${ }^{11}$, гдје се такође каже да се везник макар појављује у комбинацији с везником $\partial a$, , pеђе друкчије”, када је њиме обиљежена зависна клауза која „садржи неку претпоставку, могућност, услов”, а у комбинацији с везником што када се зависном клаузом означава „нешто стварно, реализовано, конкретно". При том се као синоними у поступку експланације у првом случају (тј. у случају везника макар да) наводе конструкције чак и ако, и у случају да (je), а у другом случају везници иако, и поред тога што.

Међутим, забиљежени примјери и оно што у литератури налазимо у вези са проблемом успостављања семантичке дистинкције међу спојевима макар што и макар да, казују нам да такву дистинкцију није могуће базирати искључиво на сложеном везнику, тачније на инхерентним семантичким карактеристикама његових интегралних дијелова што и $\partial a$. Подробније у својој студији о спојевима с ријечју макар говори И. Грицкат, истичући да спој „макар да потискује другу алтернативу и полако се генералише, тако да макар што неким језичким стручњацима чак више не изгледа правилно ${ }^{12}$, , чему, по њеном мишљењу, доприноси и чињеница да се и везници мада и премда, код којих не постоји алтернатива са што, могу употријебити „у оба семантичка одсека" (Грицкат 2004: 202). И М. Стевановић у одјељку посвећеном анализи концесивних реченица с везником макар међу примјерима наводи и реченице са спојевима макар да и макар што и закључује да без обзира на то колико је модалност датих реченица везана за једне везнике, а индикативност за друге - „сами везници ни код концесивних реченица не одређују модални или индикативни карактер њихов”, већ се он утврђује „на основу целокупности језичких прилика" (Стевановић 1979: 913).

${ }^{11}$ Подаци из Српског електронског речника.

${ }^{12}$ У вези с тим ауторка каже да је у нашим часописима било изнијетих сугестија да спој макар што не треба употребљавати, јер представља дијалектизам, и при том наглашава да је на такву употребу „наилазила много пута”. 
Како већ навођени примјери из посматраног језичког материјала показују, сложени везник макар $\partial a$ не појављује се искључиво у реченичним структурама које одликује хипотетичност садржаја, већ се јавља и у концесивним реченицама које карактерише фактивност садржаја. Другим ријечима, датим сложеним везником у српском језику могуће је обиљежити и реални и евентуално реални концесивни узрок или услов. На то директно указује примјена теста супституције. У првом је случају сложени везник макар да замјенљив везницима иако или без обзира на то што/ упркос томе што, а у другом сложеним везником и ако ( $и$ кад, и да).

\subsection{2. Парцијалноконцесивни (с партикулама ма, макар, било)}

Међу везна средства парцијалноконцесивних, комбинованих реченичних модела спадају и сложени везници настали обједињењем антепониране партикуле и лексеме замјеничког типа и/или поријекла (односно-упитне замјенице, замјеничког прилога, замјеничког придјева, везника замјеничког поријекла). У српском се језику као обавезно антепониране партикуле у улози концесивног чиниоца, способног да са неком од замјеничких лексема (ко, ито/шта, који, чији, какав, колики, како, колико, кад, гдје, куда, одакле) твори сложени везник парцијалноконцесивне семантике, употребљавају партикуле ма, макар и било, које су, уз највећи број замјеничких лексема, међусобно су супституентне.Тако формираним сложеним везником (ма ко, ма што/шта, ма који, ма какав, ма чији, ма како, ма колико, ма када, ма гдје, ма због чега (год), ма ради чега (год) ма куда, макар ко, макар кад, макар како, било ко, било шта, било који, било какав, било колики, било чији, било гдје, било куда, било када, било како, било колико) у структуру зависносложене реченице уводи се зависна клауза којом се, понајвише зависно од карактера замјеничке лексеме у саставу везника, укида ограничење у погледу идентитета субјекта, објекта, квалитета појава или предмета, у погледу комплемента семикопулативног глагола, у погледу локалне, темпоралне, квантитативне и посесивне детерминације, у погледу начина, карактера, исхода узрока или сврхе радње, што потврђују сљедећи примјери забиљежени у различитим функционалним стиловима српскога језика (најчешће у књижевноумјетничком и у жанровима публицистичког стила блиским књижевноумјетничком):

\footnotetext{
....ма ко васпитавао, уноси и скривене вредности (Б. С. Јевтић, Метода подстицања и спречавања у моралном васпитању деце и младих, Д); Мa шта човек радио, (...), у свему моја добра покојна стрина мора наћи неке опасности (Р. Домановић, Мртво море, 72-73, АСК); Ма које доба било, а чаршија закрчена колима грожђа са села (Б. Станковић, Из старог јеванђеља и стари дани, 54, АСК); ... припадник ма чије вере био, (...), не сме да пређе у Србију и у Црну Гору (ЗДИСН, 336); Муслимани дакле траже накнаду апсолутну и општу, за сва добра ма какве природе била она... (Југославија 1918-1984, 175); ...има смисла посебно посматрати српски језички стандард, у који улази све оно што Срби, ма где живели, употребљавају као свој неговани и нормирани језик (Б.
} 
Брборић, ОЈР);...ма како то изгледало страшно и мени и Никанору кад гледамо својим уморним старачким очима, она, та кожа (о, опојна, луда младости) загушила је речи које говоре о смерности и уздржљииости (Д. Ненадић, Доротеј, 79, АСК); Госпођа J. каже да никад једног ирния, ма колико он био културан, не би примила за свој сто, ... (Р. Петровић, Африка, 11, АСК); Не може се без неких простих потреба, макар како узвишен порив калио вољу (Д. Ненадић, Доротеј, 112, АСК); Осамљена иступаға, макар колико она јуначка била, воде обично поразу и непотребним жртвама... (Југославија 1918-1984, 313); Кад дође време да стараи умре, он дозове своја три сина, па их закуне да сестру даду првоме ко дође да је проси, макар ко био (АНП, 105, АСК); Макар ти ита иар казао кад се вратиш не осврћи се док намој кући не дођеш (Стевановић 1979: 913, народна приповијетка); Мислим да ће Београд, било ко од кандидата да победи, добити доброг градоначелника (Ковачевић 2009: 98, Блиц); Tragično je ma zbog čega se dečko ubio... (www.kurir-info.rs/.../decak-se-ubio-zbog-ljubavi-clanak-370586); ...njegovo je ime postalo strah i trepet za neprijatelje revolucija ma radi čega izbijale u slijedećih stotinjak godina... (www.index.hr/indexforum/postovi/.../na...); Било где живео/да живии, увек ћеш се снаћи (Мразовић 2009: 382); Било шта рекао/да каже, не веруј му (Мразовић 2010: 382); Било куд отишао/да одеш, мира нећеш наћи (Мразовић 2009: 382); Било кад дошао/да дођем, увек си добро домао (Мразовић 2009: 382).

Базични семантички однос међу клаузама наведених зависносложених реченица експлициран је замјеничком лексемом у саставу сложеног везника, а саприсуство концесивне семантичке компоненте у том односу огледа се у употреби неке од поменутих партикула (ма, макар, било), замјенљивим концесивним прилошким изразом без обзира на то. Као експонент концесивне семантичке вриједности, партикула има статус обавезног, интегралног дијела сложеног везника, јер би њено изостављање довело до промјена на структурном и семантичком плану реченице, односно до обесмишљавања садржаја реченичне структуре. Употријебљена у својству модификатора уз замјеничку лексему, она цијелој конструкцији даје концесивни карактер релативизујући значај садржаја зависне клаузе при реализовању ситуације означене управном клаузом. Употиријебљена уз замјеничку лексему или израз, она „има улогу генерализатора и релативизатора” садржаја те лексеме („садржаја везника”) и „превођења конструкције у сферу концесивног значења" (Симић \& Јовановић 2002: 1371).

\section{2. Сложени везници са постпонованом партикулом}

Сем сложених везника парцијалноконцесивне семантике насталих у процесу обједињења антепониране партикуле (ма, макар) и неке од замјеничких лексема (који, какав, колико, како и сл.), у језику постоје и сложени везници истога значењског типа са обликотворном партикулом реализованом у постпозицији замјеничке лексемеили замјеничког прилошког израза узрочно-упитног или финално-упитног значења (због чега, ради чега), каква је у савременом српском језику партикула год ${ }^{13}$. У литератури налазимо да је ова

${ }^{13} \mathrm{O}$ настанку, облицима, значењима и етимолошком идентитету партикуле год в. Прањковић 2001: 60-61. 
партикула битно обиљежје хабитуалних реченица, тј. њихов типизирајући елемент, што значи да се у сложеним реченицама са зависном клаузом уведеном овим типом сложених везника предикација надређене клаузе реализује без обзира на вршиоца радње, на предмет обухваћен радњом и на лексичко језгро именског дијела предиката зависне клаузе, на тип посесивне детерминације, и без обзира на околности типа мјесто, вријеме, начин, количина, узрок, намјера, друштво:

... Франиуска и краљевина СХС обавезују се да уреде мирним путем и на следећи начин сва питања какве год природе била она, ... (Југославија 1918-1984, 162); Већ је из овог јасно да нам је народни језик, како га год ми звали, заједничка својина и заједничко добро (Б. Брборић, ОJP); Vlada će svagda osnove i predloge, (...), svestrano ispitati i oceniti i, koliko je god, bez štete za državne potrebe, mogućno uvažiti (Устав Србије од 1869); ...али кад би год полазила по траву и по воду, свагда би прикричила ждребету да пази на њезин глас и на њезине ријечи: ... (АНП, 132, АСК); Борити се треба за бар минималну обнову ћирилице гдје је год то могуће... (Б. Брборић, ОЈР); Изаиста он је увек, где год ишао по чариији, улици, вукао, скупљао камење и трпао у недра, појасеве (Б. Станковић, Божји људи, АСК); Куд год наш домаћин и његова ђеца из дома поступали, свуд на срећу наступали! (В.С. Караџић, Здравице); Што год дете зло и погано говори, од оца је и матере чуло (Ж. Требјешанин, Представа о детету у српској култури, АСК); Чија год је била, сваки је пропао (В. Чајкановић, Мит и религија у Срба, АСК); Због чега год то учинио, није паметно поступио (Прањковић 2001: 60); Ниси то морао учинити ради чега год учинио (Прањковић 2001: 60).

Ни у једном од наведених примјера сложени везник творен додавањем партикуле год некој од замјеничких лексема није могуће замијенити ниједним везником општеконцесивне семантике (иако, мада, премда). А да је у њима саприсутно и концесивно значење, потврђује могућност употребе концесивног прилошког израза без обзира на то умјесто партикуле год, с тим што је обавезна антепозиција датог прилошког израза у односу на замјеничку лексему. Да партикула год заиста има статус интегралне компоненте сложеног везника доказује немогућност њеног испуштања из састава везника, а да при том не дође до промјена и на граматичком и на семантичком плану реченице. Елидирањем партикуле или не бисмо добили граматички прихватљиву реченицу или реченица не би имала исту семантичку вриједност коју има с датим сложеним везником:

Како год $[\rightarrow *$ Како $]$ се ова буна завриила, нама Србима мора бити друкчије; Што

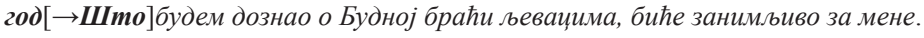

Употријебљена уз лексему замјеничког поријекла, партикула год функционише као нека врста модификатора који „odnosnu riječ uz koju stoji modificira tako da je 'osamostaljuje', i to upravo time što joj 'oduzima' odnosnost, a dodaje, kao što Raguž tvrdi, dopusnost. Upravo taj spoj odnosnosti i dopusnosti rezultira onim o čemu je ovdje u prvom redu riječ, a to je značenje habitualnosti" (Прањковић 2001: 63). Изостављањем партикуле год отвара се могућност успостављања антецедента у структури управне клаузе, тако да зависна клауза постаје релативна клауза рестриктивног типа, и обратно - присуство партикуле 
год у структури везника ништи релативно значење замјеничке лексеме, што само потврђује чињеницу да је хабитуализација у семантичкој супротности са рестриктивношћу ${ }^{14}$.

Између интегралних дијелова сложеног везника са постпонованом партикулом год може бити позиционирана замјеничка или глаголска енклитика (укључујући и ријечцу се), што је у складу са правилом о распоређивању енклитика иза везника и сличних ријечи (Поповић 2004: 292-295), односно са варирањем њиховог распореда у синдетским реченицама. Таквих је примјера у нашем корпусу мање него оних у којима се енклитика налази иза партикуле год, с тим што можемо констатовати да је учесталост њихова појављивања већа у старијој фази развитка српског стандардног језика.

Неријетко се уз везнике настале по овом творбеном моделу употребљава и везник да (који год да, какав год да, како год да, гдје год да, с ким год да и сл.), који је у датим реченичним моделима синтаксички редундантан, док се на семантичком плану додавањем овога везника истиче хипотетички карактер зависне клаузе:

Обед је тај који дефинише, окупља и одржава породииу каква год да је њена структура (Б. Ј. Провчи, Драмски рукописи А. Поповића и Д. Ковачевића, Д); Колико год да је он леп и скупоцен, Ви нисте ништа изгубили тим што сам Вас њега лишио (М. Миланковић, Кроз васиону и векове, АСК); Та температура има, како год да је та атмосфера засићена воденом паром, своју горњу границу... (М. Миланковић, Кроз васиону и векове, АСК); Где год да дође, чекаће га увек незаобилазна сарма (Ковачевић 2009: 97, М. Капор).

Сложене везнике формиране помоћу партикуле год одликује широка функционалонстилска распрострањеност. Висок степен заступљености датих везничких средстава и у књижевноумјетничким текстовима старијег поријекла, као и чињеница да су ови везници готово редовно елементи спискова везника у старијој граматичкој литератури, која се базира махом на корпусу текстова књижевноумјетничког функционалног стила, иде у прилог тврдњи да је ријеч о сложеним везницима чији настанак није везан за процес строже функционалностилске диференцијације српског језика.

\section{ЗАКљУЧАК}

Систем сложених концесивних везника један је од многобројнијих везничких система у српском језику, ако не и најмногобројнији. С обзиром на начин постанка, сложени везници концесивне семантике могу се подијелити у двије велике скупине: 1) сложене концесивне везнике формиране преко

${ }^{14}$ О комбинаторности партикуле год и везних средстава в. (Прањковић 2001: 61). 
прилошких израза приједлошко-замјеничког типа (упркос томе што, насуnрот томе ито, уз (а) све то што, поред/покрај/поврх тога ито, мимо тога ито; без обзира (на то) што, без обзира (на то)да ли;без обзира (на то) ко, без обзира (на то) који/ какав/ колики/ чији, без обзира (на то) гдје/ одакле/ откуда, без обзира (на то)када, без обзира (на то) како, без обзира (на то) колико, без обзира (на то) зашто/ због чега/ ради чега) и 2) сложене концесивне везнике творене у процесу удружења партикуле и везника или лексеме замјеничког поријекла или типа (ма ко, ма што/шта, ма који, ма какав, ма чији, ма како, ма колико, ма када, ма гдје, ма због чега (год), ма ради чега (год) ма куда, макар ко, макар кад, макар како, било ко, било шта, било који, било какав, било колики, било чији, било гдје, било куда, било када, било како, било колико; и поред тога што, који год, како год итд.). У оквиру обје скупине реализују се оба семантичка подтипа - и сложени везници општеконцесивног и сложени везници парцијалноконцесивног значења.

Према томе у којој се позицији у односу на другу интегралну компоненту сложеног везника налази партикула, издвајају се двије групе везника: 1) сложени везници концесивне семантике са антепонираном партикулом и 2) сложени везници са постпонованом партикулом (2од). Први могу бити реализовани у општеконцесивном и парцијалноконцесивном значењу, а други само парцијалноконцесивном.

Међу најфреквентније и функционалностилски најраспрострањеније сложене концесивне везнике спадају сложени везници парцијалноконцесивне семантике творени помоћу партикуле год (кад год, док год, докле год, гдје год, како год, ито год, кога год, куд год, ко год, који год). С обзиром на то да се релативно често појављују у свим функционалним стиловима српскога језика, можемо устврдити да овај тип сложених концесивних везника има карактер неспецифичних везничких средстава. Учесталост њиховог појављивања у књижевноумјетничком функционалном стилу далеко премашује учесталост појављивања осталих семантичких и структурних типова сложених концесивних везника. У овоме стилу такође се чешће јављају и сложени концесивни везници са партикулом и простим зависним везником као интегралним компонентама ( $а$ да, и да, и кад, свеједно што, макар што/да и сл.), што је у складу са његовим инхерентним карактеристикама. У погледу њихове функционалностилске репартиције публицистички стил најближи је књижевноумјетничком.У датоме стилу готово да изостају сложени концесивни везници са замјеничким прилошким изразом као интегралном компонентом (без обзира (на то)што, упркос томе што, и поред тога што и сл.). С обзиром на заступљеност сложених концесивних везника формираних преко прилошких израза приједлошко-замјеничког типа, на супротном полу од књижевноумјетничког налазе се научни и публицистички функционални стил, у којем најфреквентнију употребу има сложени везник без обзира (на то) што, при 
чему је учесталија варијанта са редукованом демонстративном замјеничком лексемом у научном стилу. У административном стилу преовлађују сложени концесивни везници са прилошким изразомбез обзира (на то), с напоменом да апсолутну доминацију има сложени везник без обзира (на то) да ли. Готово је занемарива заступљеност концесивних везника са антепонираном партикулом као обавезном интегралном компонентом. Они се готово искључиво појављују у корпусу административних текстова старијег постања.

\section{ИЗВОРИ}

АНП - Антологија народних приповедака

АСК - Антологија српске књижевности, Учитељски факултет Београд, http://www.uf.bg.ac.rs/

АСП: М. Јосић Вишњић, Антологија српских приповедача ХІХ и XX века, приређивачи електронског издања Knjizara.com и Alexandria studio (http://www.aleksandrija.com/).

Б. Брборић, ОЈР: Бранислав Брборић, О језичком расколу (Сочиолингвистички огледи I), Београд, Нови Сад: ЦПЛ, Прометеј, 2000.

Б. Брборић,СЈНЈ: Бранислав Брборић, С језика на језик (Соииолингвистички огледи II), Београд, Нови Сад: ЦПЛ, Прометеј, 2001.

ЗДИСН: Знаменита документа за историју српског народа 1538-1918, приредили Дејан Микавица, Владан Гавриловић, Горан Васин, Филозофски факултет, Нови Сад 2007.

Југославија 1918-1984:Б. Петрановић, М. Зечевић, Југославија 1918-1984. (збирка докумената), Библиотека „Сведочанства”, Издавачка радна организација „Рад”, Београд 1985.

KCСJ: Корпус савременог српског језика (www.korpus.matf.bg.ac.rs)

СДДК: Сабрана дела Данила Киша, интегрално електронско издање.

Д: http://www.uns.ac.rs/sr/doktorske/javniuvid.html

Зак. : http://www.parlament.gov.rs/акти/донети-закони/донети-закони.45.html

P: http://www.rastko.rs/književnost/

http://www.politika.rs/

http://www.gradjanski.rs

http://www.nin.co.rs

http://www.glas-javnosti.rs/ 


\section{ЛИТЕРАТУРА}

Антонић 2005: И. Антонић, „Синтакса и семантика падежа”, у: П. Пипер, И. Антонић. В. Ружић, С. Танасић, љ. Поповић, Б. Тошовић, Cuнтакса савременога српског језика: проста реченица, у редакцији М. Ивић, Београд, Нови Сад: Институт за српски језик САНУ, Београдска књига, Матица српска, 119-300.

Барић2005: E. Barić, M. Lončarić, D. Malić, S. Pavešić, M. Peti, V. Zečević, M. Znika, Hrvatska gramatika, Zagreb: Školska knjiga.

Вукојевић \& Худечек 2007: L. Vukojević, L. Hudeček, „Podrijetlo, ustrojstvo, funkcija i normativni status složenih veznika i vezničkih skupina", u: Sintaktičke kategorije, Zbornik radova znanstvenoga skupa s međunarodnim sudjelovanjem, u redakciji B. Kune, Osijek, Zagreb: Filozofski fakultet, Institut za hrvatski jezik i jezikoslovlje, 283-333.

Грицкат2004: И. Грицкат, Студије из историје српскохрватског језика, Београд: Завод за уџбенике и наставна средства.

Ђуркин 2011: В. Ђуркин, „Сложени везници концесивне семантике и процес функционалностилске диференцијације у Вуковом језику”, $C p$ пски језик, XVI, Београд, 31-242.

Ђуркин 2014: В. Ђуркин, „О сложеним везницима (и) поред тога што, (и) покрај тога што, (и) поврх тога што, (и) мимо тога што”, Радови Филозофског факултета (филолошке науке), бр. 16, књ. 1/1, Филозофски факултет Универзитета у Источном Сарајеву: Пале, 143-160.

Кликовац 2008: Д. Кликовац, „О семантици текстуалних конектора у српском језику који се састоје од предлога месних значења и поименичене заменице тај (поред тога, уз то, насупрот томе, поврх тога, при томе, према томе, иза тога, на то)", Зборник Матице српске за славистику, 73, 177-196.

Ковачевић 2002: М. Ковачевић, Синтаксичка негащија у српскоме језику, Ниш: Издавачка јединица Универзитета у Нишу.

Ковачевић 2008: М. Ковачевић, „Значај интензификатора за концесивну интерпретацију зависних реченица", у: Зборник радова са научног скупа Српски језик, књижевност и уметност, књига I, одговорни уредник: М. Ковачевић, Крагујевац: Филолошко-уметнички факултет, 65-83.

Ковачевић 2009: М. Ковачевић, Огледи из српске синтаксе, Београд, Друштво за српски језик и књижевност Србије. 
Милошевић 1986: К. Милошевић, „Синтаксички поступци за исказивање концесивних релација у сложеној реченици у српскохрватском језику и семантичка структура која се при том остварује", Научни састанак слависта у вукове дане, 15/1, Београд, МСЦ, 33-45.

Мразовић2009: P. Mrazović, Gramatika srpskog jezika za strance, Sremski Karlovci, Novi Sad: Izdavačka knjižarnica Zorana Stojanovića, Dobra vest.

Павловић 2009: С. Павловић, Старосрпска зависна речениияа од XII до XV века, Сремски Карловци, Нови Сад: Издавачка књижарница Зорана Стојановића.

Пипер 2005: П. Пипер, „Семантичке категорије у простој реченици: синтаксичка семантика", у: П. Пипер, И. Антонић. В. Ружић, С. Танасић, Љ. Поповић, Б. Тошовић, Синтакса савременога српског језика: проста реченииа, у редакцији М. Ивић, Београд, Нови Сад: Институт за српски језик САНУ, Београдска књига, Матица српска, 575-982.

Поповић1972: „О начинским реченицама с везником (а) да”, Наш језик, XIX/2-3, Београд, 155-164.

Поповић 2004: Љ. Поповић, Ред речи у реченици, Београд: Друштво за српски језик и књижевност Србије.

Прањковић 2001: I. Pranjković, Druga hrvatska skladnja, Zagreb: Hrvatska sveučilišna naklada.

CEP: Српски електронски речник, развојна верзија, www.rasprog.com.

Силић1984: J. Silić, Od rečenice do teksta, Zagreb: Liber.

Симић \& Јовановић 2002: Р. Симић, Ј. Јовановић, Српска синтакса I-II, $I I I-I V$, Београд: Јасен.

Стевановић 1979: М. Стевановић, Савремени српскохрватски језик II, Београд: Научна књига.

\section{SYSTEM OF COMPOUND CONCESSIVE CONJUNCTIONS IN SERBIAN}

\section{Summary}

System of compound concessive conjunctions is one of, if not, the most multitudinous in Serbian.The main goal of this work was to inventory, describe and classify compound concessive conjunctions according to the structural and elina semantic criteria, as 
well as discover laws connected to their functional-stylistic repartition.According to the formation model, compound concessive conjunctions may be classified into two large groups: 1) compound concessive conjunctions formed through adverbial expressions of prepositional/pronominal type (uprkos tome što, bez obzira (na to) što, etc.) and 2) compound conjunctions created in the process of joining a particle and conjunction or a lexeme of pronominal origin and/or type (makar da, makar što, i pored toga što, koji god, kako god, etc.). In both groups there realize both semantic subtypes - general concessive and partial concessive. The analysis shows that the most frequent and in a functional stylicstic way most widespread are the compound conjunctions of partial concessive semantics formed by the particle god (kad god, dok god, dokle god, gdje god, kako god etc.), while the appearance of compound concessive conjunctions with adverbial expressions is mostly connected to the special styles of the Serbian language.

Veselina V. Đurkin 